Красинский Владислав Вячеславович

доктор юридических наук, член экспертной рабочей

группы по международному антиэкстремистскому

сотрудничеству при МИД России

Красинский В.В. Участие общественного сектора в борьбе органов безопасности с терроризмом и экстремизмом // Российский журнал правовых исследований. 2015. № 1.

\title{
Участие общественного сектора в борьбе органов безопасности с терроризмом и экстремизмом
}

Аннотация: В статье анализируются основные подходы к организации взаимодействия органов безопасности и общественности в сфере противодействия терроризму. Автор рассмотрел аправления и формы взаимодействия органов безопасности с институтами гражданского общества в целях противодействия терроризму, разработал предложения по развитию сотрудничества с общественными структурами при формировании и реализации антитеррористической политики государства.

Ключевые слова: институты гражданского общества, общественные организации, органы безопасности, противодействие терроризму и экстремизму, взаимодействие органов безопасности и институтов гражданского общества.

В современных условиях терроризм превратился в фактор, оказывающий серьезное влияние на формирование социально-политической обстановки на национальном, региональном и международном уровне.

Сегодня можно констатировать усложнение генезиса терроризма. Расширился спектр негативных явлений в различных сферах, которые приводят к воспроизводству терроризма и разрастанию его масштабов. Разнообразен круг идеологических концепций террористической направленности. 
В этой связи необходимо комплексно подходить к вопросам борьбы с терроризмом и совместно с общественными структурами решать весь спектр имеющихся социально-политических, идеологических и иных противоречий. Для этого требуется взаимодействие и координация всех «здоровых» сил гражданского общества, заинтересованных в решении проблемы, которая стала весьма актуальной.

Как элемент общегосударственной системы противодействия терроризму органы безопасности принимают участие в реализации мер по предупреждению, пресечению и профилактике терроризма, однако предпринимаемых ими самостоятельных усилий недостаточно для устранения причин и условий, способствующих террористической деятельности, осуществления информационного противодействия терроризму. Необходимо совместно с общественными структурами своевременно выявлять, оценивать, предупреждать и устранять террористические угрозы, оказывать адекватное воздействие на их носителей. Для этого нужно побуждать граждан к оказанию помощи органам безопасности, предметно взаимодействовать с институтами гражданского общества, целенаправленно привлекать общественные структуры к проводимой государством работе по противодействию терроризму и координировать эту деятельность.

Организация взаимодействия органов безопасности с институтами гражданского общества базируется на объективно существующих совместных задачах по противодействию террористической деятельности, в качестве которых можно выделить:

мониторинг межнациональных и межконфессиональных отношений, протестной активности населения;

принятие профилактических мер по недопущению терроризма; проведение научных исследований и различных экспертиз, подготовка аналитических и справочных материалов по проблеме противодействия терроризму; 
предупреждение легализации и активизации деятельности общественных объединений и групп радикально настроенных граждан, допускающих и оправдывающих террористические методы.

Целями такого взаимодействия являются формирование доверия и общественной поддержки работы спецслужб, максимальное привлечение к совместной деятельности представителей гражданского общества, активная наработка и взаимовыгодное использование передового опыта государственно-частного партнерства в сфере противодействия терроризму и экстремизму.

Выступая 20 декабря 2012 года на торжественном вечере, посвященном Дню работника органов безопасности, Президент России В.В. Путин особо подчеркнул, что «спецслужбы должны опираться на поддержку общества, дорожить гражданским доверием, строго следовать нормам закона, быть в постоянном диалоге с людьми» ${ }^{1}$.

В целях реализации конкретных направлений взаимодействия и координации совместной деятельности органов безопасности с институтами гражданского общества по инициативе Общественной палаты Российской Федерации в 2007 году был создан Общественный совет при ФСБ России ( далее - Общественный совет).

За 7 лет работы Общественный совет стал площадкой развития диалога и партнерства между обществом и органами безопасности.

На заседаниях Общественного совета рассматриваются инициативы общественных объединений, научных организаций и граждан в области защиты прав человека, обеспечения безопасности государства, противодействия терроризму и иным формам экстремизма. Члены Общественного совета привлекают общественные объединения и представителей СМИ к обсуждению вопросов, касающихся недопустимости

${ }^{1}$ Выступление Президента Российской Федерации В.В.Путина на торжественном вечере, посвященном Дню работника органов безопасности. URL: http://президент.pф /выступления/17174 (дата обращения: 09.01.2014) 
злоупотребления свободой слова в террористических и экстремистских целях, противодействия попыткам дискредитации органов безопасности и их сотрудников, задействованных на линии противодействия терроризму.

Общественный совет принимает участие в экспертной и законотворческой работе в сфере уголовного и уголовно-процессуального права по вопросам противодействия терроризму и экстремизму, организует благотворительную помощь. При поддержке Общественного совета ежегодно оказывается целевая материальная помощь и приобретаются квартиры родителям и семьям сотрудников органов безопасности, погибших при исполнении служебных обязанностей при проведении контртеррористических операций, организуется лечение и оздоровительный отдых детей погибших сотрудников, осуществляется социальная поддержка пенсионеров и ветеранов органов безопасности, реализуется пилотный проект по накоплению денежных средств и оплаты обучения в вузах детей погибших сотрудников органов безопасности ${ }^{2}$.

Значительный вклад в оказание оперативной адресной помощи семьям сотрудников органов безопасности, погибших в контртеррористических операциях, вносит «Национальный благотворительный фонд». За 15 лет его деятельности для семей погибших сотрудников приобретено 385 квартир, 144 семьи получили средства на ремонт жилья ${ }^{3}$. Активное участие в финансировании и реализации благотворительных программ принимают представители социально ответственного бизнеса.

Анализ деятельности Общественного совета, а также практика сотрудничества органов безопасности с общественными объединениями, некоммерческими организациями и СМИ позволяет выделить ряд актуальных направлений и организационных форм взаимодействия органов безопасности

\footnotetext{
${ }^{2}$ В 2007 г. на совещании членов Общественного совета с Московским советом ректоров вузов был выработан механизм внеконкурсного зачисления детей сотрудников органов безопасности, погибших при контртеррористических операциях.

${ }^{3}$ ФСБ: за и против. 2014. № 1. С. 6.
} 
с институтами гражданского общества в целях противодействия терроризму и иным формам экстремизма.

Первое направление можно обозначить как организащуию информационного обеспечения противодействия террористической деятельности с участием представителей институтов гражданского общества. В рамках данного направления главное внимание уделяется взаимодействию органов безопасности со СМИ. Так, Общественным советом проводится ежегодный конкурс «Журналисты России против террора», направленный на определение лучшего журналистского материала антитеррористической направленности.

Действенной организационной формой взаимодействия с институтами гражданского общества является проведение пресс-конференций и брифингов по вопросам информационного противодействия терроризму с привлечением федеральных и региональных СМИ, сотрудников НАК и руководителей органов безопасности.

Под эгидой Общественного совета осуществляется выпуск журнала «ФСБ: ЗА и ПРОТИВ», готовятся специализированные тематические фото и видеоматериалы.

Реализация данного направления взаимодействия нацелена на широкое привлечение журналистского сообщества к участию в информационном противодействии идеологии терроризма, формирование у граждан неприятия террористических и экстремистских взглядов, воспитание бдительности и готовности противостоять террористическим угрозам ${ }^{4}$.

Вторым направлением взаимодействия органов безопасности с институтами гражданского общества можно назвать профилактическую

${ }^{4}$ C 2008 года Общественным советом при ФСБ России и НАК было проведено 7 Всероссийских конкурсов «Журналисты России против террора», проведено более 20 брифингов, «круглых» столов и пресс-конференций, посвященных информационному противодействию терроризму и экстремизму, организована Всероссийская научнопрактическая конференция на тему «Роль федеральных органов государственной власти и средств массовой информации в противодействии идеологии терроризма». 
деятельность по противодействию терроризму с участием представителей институтов гражданского общества.

Особое внимание при этом уделяется профилактической работе в молодежной среде. Данное направление реализуется путем организации и проведения молодежных научно-практических конференций, студенческих фестивалей и слётов антитеррористической направленности. Целью такого формата мероприятий является повышение уровня толерантности, устранение предпосылок этнонациональных, религиозных, идеологических, социальных и политических противоречий, публичное осуждение идей экстремизма и терроризма. С 2009 года при участии Общественного совета при ФСБ России и НАК было организовано и проведено более 15 массовых молодежных мероприятий, посвященных профилактике террористической и экстремистской деятельности. Среди них ежегодные молодежные фестивали и форумы «Экстремизму - нет», ежегодные межнациональные форумы «Мир Кавказу», молодежный слет «Молодежь против терроризма, экстремизма и ксенофобии».

В качестве третьего направления взаимодействия органов безопасности с институтами гражданского общества следует обозначить организащию экспертно-консультативной деятельности по противодействию терроризму с участием представителей институтов гражданского общества.

Осуществляя эту работу, органы безопасности организуют совместно с представителями институтов гражданского общества экспертизу учебных материалов и религиозной литературы на предмет еe соответствия законодательству, представители общественных структур привлекаются к консультациям по уголовным делам о преступлениях террористической направленности.

Исключительно важным является общественный контроль за соблюдением органами безопасности конституционных прав и свобод граждан Российской Федерации. Общественный совет прочно утвердился как самостоятельный институт, способствующий эффективному общественному 
контролю над процессом осуществления государством его функций в области обеспечения безопасности, противодействия терроризму и экстремизму.

О росте влияния Общественного Совета свидетельствует тот факт, что в 2010 г. Президент РФ Д. Медведев поручал Директору ФСБ России А. Бортникову организовать рассмотрение Общественным Советом ряда проектов правовых актов, определяющих порядок вынесения гражданам официального предостережения. Это поручение главы государства было выполнено. Позднее совместно с Общественной палатой РФ Совет проводил общественные слушания по обсуждению проектов федеральных законов «О внесении изменений в Федеральный закон «О противодействии терроризму», «О внесении изменений в статью 13.1 Федерального закона «О Федеральной службе безопасности», «Об общественном контроле», «О патриотическом воспитании граждан Российской Федерации».

В целях защиты интересов граждан и общественных организаций при осуществлении основных направлений деятельности органов безопасности Общественный совет ведет активную работу с обращениями граждан. Количество обращений граждан на обычную и электронную почту os@fsb.ru неуклонно растет. Если в начальный период деятельности Совета их поступало около 20 в год, то в 2012 г. было рассмотрено свыше 400 обращений. Этот факт уже сам по себе свидетельствует о росте авторитета Совета, повышении интереса общества к его деятельности.

Однако при всей очевидности необходимости конструктивного взаимодействия органов безопасности с институтами гражданского общества в сфере противодействия терроризму необходимо отметить ряд объективно имеющихся противоречий.

У линейных подразделений органов безопасности отсутствует четкое представление о потенциале гражданского общества и возможностях общественных организаций по противодействию терроризму и иным формам экстремизма. Многие сотрудники органов безопасности серьезно не воспринимают идею задействования ресурсов гражданского общества, 
аргументируя свою позицию диаметрально противоположными оценками различными общественными силами одних и тех же процессов и явлений, высоким уровнем ангажированности многих организаций гражданского общества, стремлением их лидеров использовать складывающуюся политическую конъюнктуру в узкокорпоративных целях.

Отмечаются факты использования отдельными лидерами общественных организаций различных форм взаимодействия с органами безопасности для личного пиара, участия в распределении бюджетных средств, выделяемых в рамках региональных программ профилактики межнациональных и межконфессиональных отношений.

Со своей стороны общественный сектор, не имея сведений о потребностях органов безопасности в области диалога с институтами гражданского общества по вопросам противодействия терроризму и экстремизму, не проявляет инициативы по выстраиванию взаимодействия с органами безопасности на данном участке.

Перечисленные проблемы требуют решения и принятия конкретных мер по развитию сотрудничества с общественными структурами при формировании и реализации антитеррористической политики государства. В этой связи представляется целесообразным:

1. В рамках информационного противодействия терроризму органам безопасности следует, на наш вгляд, шире использовать возможности экспертного сообщества и сетевых структур гражданского общества для недопущения распространения информации, оправдывающей экстремизм и терроризм под прикрытием идей защиты социальной справедливости, активно «продвигать» контрпропагандистские материалы, дискредитирующие идеологов терроризма и экстремизма, сопровождать разработку, общественные слушания и принятие правовой базы, позволяющей осуществлять выявление, предупреждение и пресечение террористической и иной экстремистской деятельности в открытых телекоммуникационных сетях. 
2. В целях устранения причин и условий, способствующих террористической деятельности, необходимо привлекать институты гражданского общества для организации и проведения мероприятий по содействию межнациональному и межконфессиональному диалогу, развивать программы государственно-частного партнерства по интеграции в мирную жизнь (переезд, трудоустройство, социальная защита) лиц, возвратившихся из мест лишения свободы, последовательно восстанавливать доверие населения к правоохранительным органам, оперативно информировать граждан о мерах предосторожности в период усиления террористических угроз 5 .

3. Заслуживает пристального внимания экспертно-консультативная деятельность по противодействию терроризму. Значительным потенциалом обладает привлечение научной общественности, неправительственных организаций, общественных советов, палат и молодежных движений к проведению научных, аналитических и социологических исследований, связанных с разработкой и реализацией мероприятий антиэкстремистской и антитеррористической направленности, обоснованием и реализацией методик формирования у населения антитеррористической идеологии и мотивации антитеррористического поведения, валидных методик оценки и признания материалов экстремистскими и др.

Как представляется, реализация указанных перспективных направлений взаимодействия органов безопасности с институтами гражданского общества позволит государству и обществу адекватно реагировать на возникающие террористические угрозы, а также будет способствовать решению функциональных задач органов безопасности по обнаружению, вскрытию террористической деятельности, предупреждению и пресечению противоправных акций.

\footnotetext{
${ }^{5}$ В настоящее время при участии Общественного совета организовано взаимодействие НАК с Ситуационным центром компании ОАО «Мегафон» в целях оповещения населения о террористических угрозах.
} 
Красинский Владислав Вячеславович

доктор юридических наук, член Общественного

консультативного научно-методического Совета

при ЦИК России

109012, г. Москва, Б. Черкасский пер. д. 4 стр. 2

\section{Список источников и литературы:}

1. Выступление Президента Российской Федерации В.В.Путина на торжественном вечере, посвященном Дню работника органов безопасности. URL: http://президент.pф /выступления/17174 (дата обращения: 09.01.2014)

2. http:// nac.gov.ru/ nakmessage/2013/12/24/v-moskve-pod-rukovodstvompredsedatelya-nak-direktora-fsb-rossii-av-bortnikova.html (дата обращения: 10.11 .14 г.)

3. Материалы IV Всерос. науч.-практ. конф. (т.1). М.: РГУНГ, 2013. С. 33-34.

4. ФСБ: за и против. 2014. № 1. М.: Издательское агентство А 2, С. 6.

5. ФСБ: за и против. 2012. № 3. М.: Издательское агентство А 2, 2014. С. 2. 